\title{
ASSESSMENT GUIDELINES OF WALL-DIAPHRAGM CONNECTIONS FOR MASONRY BUILDINGS
}

\author{
Abdul Razak Abdul Karim ${ }^{1}$, Pierre Quenneville ${ }^{2}$, Norazzlina M.Sa'don ${ }^{3}$ and Jason Ingham ${ }^{4}$ \\ ${ }^{1,3}$ Department of Civil Engineering, Faculty of Engineering, University of Malaysia \\ Sarawak, Kota Samarahan, Sarawak, Malaysia \\ ${ }^{2,4}$ Department of Civil \& Environmental Engineering, The University of Auckland, \\ Auckland, New Zealand
}

\begin{abstract}
The connections between walls and diaphragm in masonry buildings typically consist of two major parts, which are masonry wall anchorages and timber diaphragm connections. From the NZNSEE (1995) and FEMA (2006) guidelines, the connection strength values given by both guidelines are apparently related only with the possible failures of the masonry wall anchorages, and no procedures are currently available to identify the strength values related to failure of the timber diaphragm connections. This is important to consider as the minimum strength value that will govern the wall-diaphragm connection capacity can be acquired from the timber diaphragm connections. To counter this limitation, this study recommends a set of design equations to assess the strength of the timber diaphragm connections. By using these equations, in addition to the default connection strength values provided by the current guidelines, the expected strength level of wall-diaphragm connections can be accurately assessed.
\end{abstract}

Keywords: Diaphragm connections, masonry buildings, bolted connections, timber connections, URM buildings, unreinforced masonry buildings.

\section{Introduction}

Unreinforced masonry (URM) buildings are typically the class of structures with the highest risk of failure during an earthquake, and the requirement to seismically upgrade these earthquake damage-prone buildings in New Zealand was mandated by The Building Act 2004 (DBH 2004). Importantly, these URM buildings form a significant percentage of New Zealand's building stock and represent the predominant national architectural heritage (Russell and Ingham 2008). Most URM buildings in New Zealand consist of solid URM bearing walls and diaphragms (as floor and roof) made of native New Zealand hardwoods such as Kauri, Rimu or Matai. The support conditions of diaphragms were identified to be seated on or slotted into the unreinforced masonry walls.

Following the 1931 Hawke's Bay earthquake, most URM buildings were seismically retrofitted, which included the installation of wall-floor and wall-roof connections (Blaikie and Spurr 1992). Most wall-diaphragm connections that were installed as seismic retrofits were through-bolt anchors, used in conjunction with a steel bearing plate located on the exterior of the building (i.e. wall anchors) and a bolted connection on the timber diaphragm joist. The bolted connections applied to the timber members of the diaphragms were typically two bolts with $12 \mathrm{~mm}$ in diameter. The steelwood (i.e. single shear) connections were usually determined where the steel plates from $6 \mathrm{~mm}$ to $10 \mathrm{~mm}$ thick were typically used (Abdul Karim 2012).

Referring to the guidelines published by the New Zealand National Society for Earthquake Engineering (NZNSEE 1995) and Federal Emergency Management Agency (FEMA 2006), none of the wall-diaphragm 
connection details provide guidelines on the steel cleat to timber connection. The connection strength values given by both guidelines are apparently related only with the possible failures of the masonry wall anchorages. The failure mode of bolted timber connections is important to consider as the minimum strength value that will govern the wall-diaphragm connection capacity can be acquired from the diaphragm connections. Further, the current 2006 NZSEE guidelines were identified to provide only a revision on the connection strength values for wall anchorages.

From the current standard for timber structures of New Zealand (NZS 3603: 1993), the design of bolted connections was developed based on a ductile failure. The use of this standard can lead to an inaccurate strength assessment of timber bolted connections in unreinforced masonry buildings. Thus, the study was performed primarily to evaluate the strength of bolted connections for existing indigenous New Zealand hardwoods in order to provide a comprehensive assessment guideline for assessing the wall-diaphragm connections. In this study, the use of European Yield Model and Row Shear Model equations to assess the bolted connection strength in New Zealand hardwoods is recommended.

\section{Timber Properties Determination}

In order to determine the properties of timbers used, the moisture content and density, embedding strength, and compression strength tests were performed. The main purpose of the tests is to provide the basic parameters that are required in the prediction of the bolted connection strength values. The density of timbers is essential in calculating the shear strength of the connections using the Row Shear Model equation. The embedding strength of timbers is required for the bolted connection strength calculation using the European Yield Model. The compression strength perpendicular to the grain of timber was determined in order to consider the effect of the timber joists being compressed by the masonry walls if they are slotted into the walls. The moisture content of timbers was also determined as it will affect the load carrying capacities of the connections. Details of results can be found in Abdul Karim et al. (2011).

\section{Bolted Connection Tests}

\subsection{Materials}

In the laboratory tests of bolted connections, recycled native New Zealand hardwood such as Matai and Rimu were used. This is because the floor and roof diaphragms in New Zealand unreinforced masonry buildings are typically constructed using such wood species. The cross-section of each wood specimen used was $50 \mathrm{~mm}$ (thickness) $\times 100$ $\mathrm{mm}$ (width) and had an average moisture content of $13 \%$ at the time of testing. The diameter of bolts $\left(\mathrm{d}_{\mathrm{f}}\right)$ used were $12 \mathrm{~mm}$ with shank length of $70 \mathrm{~mm}$ to avoid the bolt thread in contact with the wood specimens. All bolts used were 4.8 grade and in accordance with DIN EN ISO 898-1: 1999. The fastener tensile strength $\left(f_{\text {up }}\right)$ and yield strength $\left(\mathrm{f}_{\mathrm{yf}}\right)$ were $400 \mathrm{MPa}$ and $320 \mathrm{MPa}$, respectively. A total of four steel side plates with an ultimate tensile strength, $\mathrm{f}_{\mathrm{up}}$, of 400 MPa were used in these connection tests, where the thickness of the plates was $10 \mathrm{~mm}$. The four steel plates were reused for the entire tests conducted as no significant bearing was observed on all four plates used.

\subsection{Specimen configurations}

All test specimens consisted of three-member connections with two steel side plates at each end sandwiching a wood center piece as shown in Figure 1. Eleven groups of different configurations of specimens were tested, where each group comprised of at least ten replicates. Refer to Figure 2 for a definition of the variables used and to Table 1 for the specimen configuration details. Each specimen consisted of an identical configuration of bolted connections at both 
ends. In order to ensure two independent connections achieved in all specimens, a minimum distance of $400 \mathrm{~mm}$ between connections was applied. The minimum distance chosen is in compliance with ISO/DIS 10984-2 (2008). In order to maximize the number of observations on the row shear failure mechanisms, groups with 50 $\mathrm{mm}$ end distance were tested. This subsequently enabled determination of the calibration factor in Row Shear equation to predict the row shear capacity of New Zealand hardwoods.

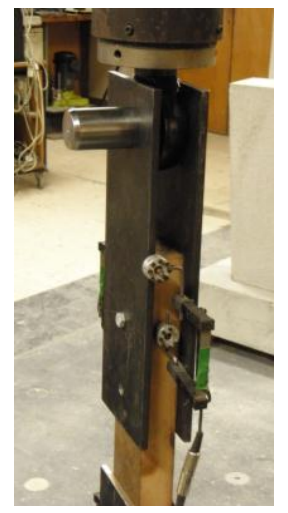

Figure 1. Typical specimen of bolted timber connection loaded parallel to the grain in a testing apparatus.

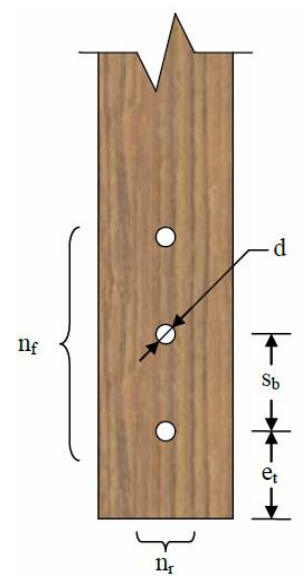

Figure 2. Definitions of the variables used.
Table 1. Specimen configuration details.

\begin{tabular}{lcccccl}
\hline Group & $\begin{array}{c}\mathrm{d} \\
(\mathrm{mm})\end{array}$ & $\begin{array}{c}\mathrm{e}_{\mathrm{t}} \\
(\mathrm{mm})\end{array}$ & $\begin{array}{c}\mathrm{s}_{\mathrm{b}} \\
(\mathrm{mm})\end{array}$ & $\mathrm{n}_{\mathrm{r}}$ & $\mathrm{n}_{\mathrm{f}}$ & Species \\
\hline 1 & 12 & 200 & 100 & 1 & 2 & Matai \\
2 & 12 & 150 & 100 & 1 & 2 & Matai \\
$2 \mathrm{R}$ & 12 & 150 & 100 & 1 & 2 & Rimu \\
3 & 12 & 100 & 100 & 1 & 2 & Matai \\
$3 \mathrm{R}$ & 12 & 100 & 100 & 1 & 2 & Rimu \\
4 & 12 & 50 & 100 & 1 & 2 & Matai \\
5 & 12 & 200 & - & 1 & 1 & Matai \\
6 & 12 & 150 & - & 1 & 1 & Matai \\
7 & 12 & 100 & - & 1 & 1 & Matai \\
8 & 12 & 50 & - & 1 & 1 & Matai \\
9 & 12 & 50 & 150 & 1 & 2 & Matai \\
10 & 12 & 50 & 50 & 1 & 3 & Matai \\
11 & 12 & 50 & 50 & 1 & 4 & Matai \\
\hline
\end{tabular}

\subsection{Instrumentation and test procedures}

All specimens were loaded in tension parallel to the timber grain up to the ultimate capacity of one of the two extremities of the connections using an MTS loading system. Finger tight force was applied to all fasteners to permit self-alignment of the test specimens, and a monotonic tension load was applied through the steel side plates. Each specimen was tested at a displacement-control rate of $0.9 \mathrm{~mm}$ per minute $(\approx 0.015 \mathrm{~mm}$ per second $)$ until failure, when the load dropped with no recovery. Both ends of each specimen were monitored for load and displacement, and the ultimate load that was recorded was for the extremity that failed. Two portal strain gauges were used to measure the displacement of the wood internal member with reference to the side steel plate at each extremity. Each load-displacement data was collected by a data acquisition system and recorded on a personal computer. The type of failure of each specimen was also recorded.

\subsection{Test results}

The test results of the eleven groups tested are given in columns 5,6 and 7 of Table 2. The average experimental values, $\mathrm{R}_{\mathrm{avg}}$, were determined and the lower 5th percentile 
Table 2. Comparison between test results and predictions.

\begin{tabular}{|c|c|c|c|c|c|c|c|c|c|c|}
\hline \multirow[b]{2}{*}{ Group } & \multirow[b]{2}{*}{$\begin{array}{c}e_{t} \\
(\mathrm{~mm})\end{array}$} & \multirow[b]{2}{*}{$\begin{array}{c}\mathrm{s}_{\mathrm{b}} \\
(\mathrm{mm})\end{array}$} & \multirow[b]{2}{*}{$\mathrm{n}_{\mathrm{f}}$} & \multicolumn{4}{|c|}{ Experimental results } & \multirow{2}{*}{$\begin{array}{c}\text { NZS 3603: } 1993 \\
\mathrm{~N}_{\min } \\
(\mathrm{kN})\end{array}$} & \multirow{2}{*}{$\begin{array}{l}\frac{E Y M}{R_{\min }} \\
(\mathrm{kN})\end{array}$} & \multirow{2}{*}{$\begin{array}{c}\text { Row Shear } \\
\mathrm{R}_{\mathrm{r} \mathrm{rs}} \\
(\mathrm{kN})\end{array}$} \\
\hline & & & & $\begin{array}{r}\mathrm{R}_{\mathrm{avg}} \\
(\mathrm{kN})\end{array}$ & $\begin{array}{r}\mathrm{CoV} \\
(\%)\end{array}$ & $\begin{array}{l}\mathrm{R}_{5^{\text {th }} \%} \\
(\mathrm{kN})\end{array}$ & $\begin{array}{l}\text { Failure } \\
\text { mode }\end{array}$ & & & \\
\hline (1) & (2) & (3) & (4) & (5) & (6) & (7) & (8) & (9) & (10) & (11) \\
\hline 1 & 200 & 100 & 2 & 75 & 8 & 66 & B & 42 & 60 & 50 \\
\hline 2 & 150 & 100 & 2 & 75 & 11 & 62 & B & 42 & 60 & 50 \\
\hline $2 \mathrm{R}$ & 150 & 100 & 2 & 66 & 7 & 59 & B & 42 & 55 & 45 \\
\hline 3 & 100 & 100 & 2 & 75 & 13 & 58 & B & 42 & 60 & 50 \\
\hline $3 \mathrm{R}$ & 100 & 100 & 2 & 66 & 14 & 50 & B & 42 & 55 & 45 \\
\hline 4 & 50 & 100 & 2 & 40 & 22 & 25 & RS & 42 & 60 & 25 \\
\hline 5 & 200 & - & 1 & 44 & 12 & 35 & B & 21 & 30 & 50 \\
\hline 6 & 150 & - & 1 & 40 & 11 & 32 & B & 21 & 30 & 38 \\
\hline 7 & 100 & - & 1 & 41 & 16 & 30 & B & 21 & 30 & 25 \\
\hline 8 & 50 & - & 1 & 16 & 11 & 13 & RS & 21 & 30 & 13 \\
\hline 9 & 50 & 150 & 2 & 32 & 26 & 18 & RS & 42 & 60 & 25 \\
\hline 10 & 50 & 50 & 3 & 43 & 35 & 18 & RS & 62 & 91 & 38 \\
\hline 11 & 50 & 50 & 4 & 54 & 35 & 23 & RS & 83 & 121 & 50 \\
\hline
\end{tabular}

strength of the test results, $\mathrm{R}_{5^{\text {th }} \%}$, was calculated assuming a normal distribution. The predominant modes of failure observed after testing are also listed in column 8 , where $\mathrm{B}$ and $\mathrm{RS}$ are designated for bearing and row shear, respectively. The 5th percentile strength prediction values for each group of connections (columns 9 to 11) are calculated for comparison. The values in column 9 and represent the minimum 5 th percentile strength of three-member type bolted connections parallel to the timber grain predicted using equations provided in NZS 3603: 1993. The 5th percentile strength values of EYM (column 10) were predicted based on the European Yield Model for double shear joint (Blass, 2003), whereas the values given are the lowest predicted strength from the EYM equations. The Row Shear Model equation proposed by Quenneville (2009), which is used to predict the strength of connections that fail in a row shear mode, is also given in column 11. The calibration factor determined for the tested wood species (Abdul Karim 2012) is applied to the Row Shear Model equation. All strength values were calculated for short term duration of load (i.e. seismic loading), as per Table 2.4 of NZS 3603: 1993.
The effectiveness of various equations (i.e. NZS 3603: 1993, EYM, and $R_{r}$ rs in predicting the strength of bolted connections in New Zealand hardwood is demonstrated by comparing the 5 th percentile prediction values with the 5th percentile test results obtained. A graph showing the effectiveness of the strength prediction equations versus the test results is plotted in Figure 3. Any prediction values plotted below the $45^{\circ}$ line are considered to be conservative or safe.

By referring to groups that failed in bearing, predictions using the current NZS 3603: 1993 were found to be too conservative compared to the lower 5th percentile of the experimental results. The strength values provided by the NZS 3603: 1993 would make the assessment of walldiaphragm connections in New Zealand unreinforced masonry buildings inaccurate. Excluding Groups 4, 8, 9, 10 and 11 for which the connections failed in row shear, the ratio of the timber standard values to the test results varies between 0.59 and 0.83 , with an average of 0.68. Better prediction values were obtained using the EYM equations with the same ratio ranges from 0.85 to 1.10 and an average of 0.97 . 
A similar comparison was performed for the groups of connections that failed in row shear (Groups 4, 8, 9, 10 and 11). Both the EYM and NZS 3603: 1993 were clearly over predicting the strength (i.e. unsafe) with an unacceptable percentage of error. Good prediction values were obtained using the row shear equation, especially for Groups 4 and 8 with ratios of 0.99 and 0.98 , respectively. However, the strength of Groups 9, 10 and 11 was over predicted with a ratio of 1.38, 2.08 and 2.17 , respectively. These over prediction values are mainly due to the variations of experimental results obtained as factors that could influence the connection strength such as moisture content, slope of grain and knot occurrence were examined in all specimens for Groups 9, 10 and 11.

From the comparisons made above, the use of the current equations (i.e. NZS 3603: 1993, EYM and row shear) to estimate the New Zealand hardwood bolted connection strength was verified. The use of the EYM equations in combination with the one for row shear would thus form a better set of equations for predicting the connection capacity. Thus, an assessment of existing wall-diaphragm connections in New Zealand unreinforced masonry buildings is attainable.

\section{Assessment Guidelines}

As the legislative requirements defined in The Building Act 2004 (DBH, 2004) and interpreted by the New Zealand Society for Earthquake Engineering (NZSEE, 2006), an earthquake-prone building is essentially categorized as a building that performs in a design earthquake at a level less than onethird of the New Building Standard (NBS) percentage level. In order to determine the NBS percentage level, a step by step procedure for assessing unreinforced masonry buildings was developed in particular to measure the performance of wall-diaphragm connections subjected to lateral seismic loading. This was done by comparing the force demand and capacity of the connections.
The force demand was determined using the Equivalent Static Analysis (ESA) as this method is suitable for application for low rise unreinforced masonry buildings in New Zealand. The wall anchorage and the diaphragm connection capacities are determined using the default values and design equations 1 and 2 as given in Sections 4.1 and 4.2, respectively, with the assumptions that the timber diaphragms are intact and do not fail before the walldiaphragm connection. By implementing this procedure, the expected performance level of wall-diaphragm connections can be quantitatively and quickly assessed and remedied if necessary.

\subsection{Wall anchorage capacity}

The default strength values of wall anchorages provided in Table 10B.2 of NZSEE (2006) may be adopted for bolts connecting components to masonry.

\subsection{Diaphragm connection capacity}

The capacity of a bolted connection shall be determined using the following equations, whereas the minimum value will govern the connection capacity.

i. Capacity of connection parallel to loading directions (refer to Figure 4)

$$
\mathrm{R}_{\square}=\operatorname{Min}\left\{\begin{array}{l}
\text { European Yield } \operatorname{Model}\left(\mathrm{R}_{\mathrm{EYM}}\right) \\
\text { row shear failure of timber }\left(\mathrm{R}_{\mathrm{rrs}}\right) \\
\text { bolt in shear }\left(\mathrm{V}_{\mathrm{f}}^{*}\right) \\
\text { steel rod in tension }\left(\mathrm{N}_{\mathrm{rod}}^{*}\right) \\
\text { steel plate in bearing }\left(\mathrm{V}_{\mathrm{b} 1}^{*}\right) \\
\text { steel plate in tearing out }\left(\mathrm{V}_{\mathrm{b} 2}^{*}\right)
\end{array}\right.
$$

ii. Capacity of connection perpendicular to loading directions (refer to Figure 5)

$$
\mathrm{R}_{\perp}=\operatorname{Min}\left\{\begin{array}{l}
\text { timber member in bearing }\left(\mathrm{F}_{\mathrm{b}}\right) \\
\text { washers bearing }\left(\mathrm{F}_{\mathrm{c}}\right) \\
\text { bolt in tension }\left(\mathrm{N}_{\mathrm{tf}}^{*}\right) \\
\text { steel rod in shear }\left(\mathrm{V}_{\mathrm{rod}}^{*}\right) \\
\text { steel plate in bearing }\left(\mathrm{V}_{\mathrm{b} 1}^{*}\right) \\
\text { steel plate in tearing out }\left(\mathrm{V}_{\mathrm{b} 2}^{*}\right)
\end{array}\right.
$$




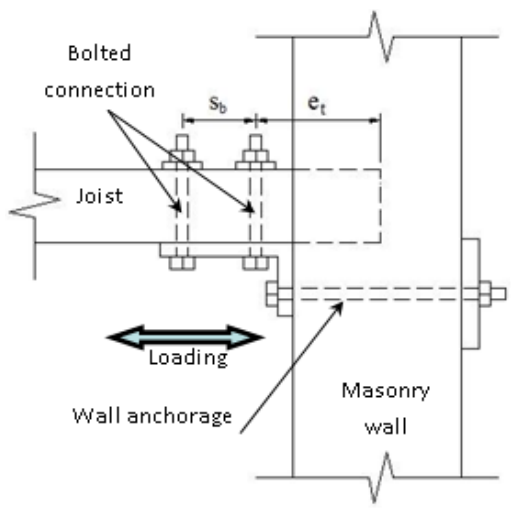

Figure 4. Connection parallel to loading directions.

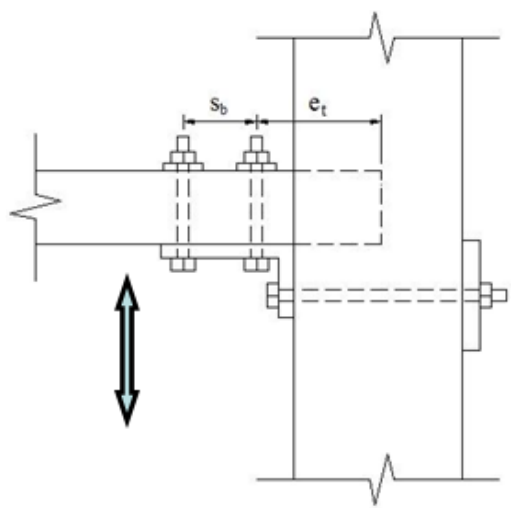

Figure 5. Connection perpendicular to loading directions.

\section{Conclusions}

In addition to the default connection strength values provided by the NZSEE guidelines to assess the wall anchorages, this study provides a set of equations to assess the diaphragm connections. This promotes a complete procedure to assess the strength of the walldiaphragm connections in New Zealand unreinforced masonry buildings and an inaccurate strength assessment can be avoided.

\section{Acknowledgments}

The authors would like to express gratitude to the New Zealand Foundation for Research, Science and Technology (FRST) for providing funding for this project, and to the Ministry of Higher Education (MOHE) Malaysia and Universiti Malaysia Sarawak (UNIMAS) for their financial support of the first author.

\section{References}

Abdul Karim, A. R. (2010). "Seismic Assessment of Wall-Diaphragm Connections in New Zealand URM Build-ings." PhD thesis, The University of Auckland, NZ.

Abdul Karim, A. R., Quenneville, P., M.Sa'don, N., and Ingham, J. M. (2011). "Wall-Diaphragm Connection Assessment Guidelines for URM Buildings." $9^{\text {th }}$ PCEE, Auckland, NZ.

Blaikie, E. L., and Spurr, D. D. (1992). "Earthquake Vulnerability of Existing Unreinforced Masonry Buildings." Works Consultancy Services, Wellington, NZ.

Blass, H. J. (2003). "Joints with Dowel-type Fasteners." Timber Engineering, S. Thelandersson and H. J. Larsen, eds., John Wiley \& Sons Ltd., England, pp. 315-331.

Department of Building and Housing (2004). "The Building Act 2004." DBH - Te Tari Kaupapa Whare, Wellington, NZ, $116 \mathrm{p}$.

FEMA (2006). "Techniques for the Seismic Rehabilitation of Existing Buildings." FEMA 547, FEMA, Washington, D.C.

ISO (2008). Draft International Standard ISO/DIS 10984-2 Timber structures - Dowel-type fasteners - Part 2: Determination of embedding strength and foundation values. ISO, Geneva, SUI.

NZNSEE (1995). Draft Guidelines for Assessing and Strengthening Earthquake Risk Buildings, NZNSEE, Wellington, NZ.

NZSEE (2006). Assessment and Improvement of the Structural Performance of Buildings in Earthquakes, NZSEE, Wellington, NZ.

Quenneville, P. (2009). "Design of Bolted Connections: A Comparison of a Proposal and Various Existing Standards." Journal of SESOC New Zealand Inc., 22 (2), pp. 57-62.

Russell, A. P., and Ingham, J. M. (2008). "Trends in Architectural Characterisation of Unreinforced Masonry in New Zealand." $14^{\text {th }}$ $\mathrm{IB}^{2} \mathrm{MaC}$, Sydney, AU.

SNZ (1993). NZS 3603: 1993 Timber Structures Standard. SNZ, Wellington, NZ. 